[Agr. Biol. Chem., Vol. 36, No. 9, p. 1489 1496, 1972]

\title{
Structure of Phrymarolin-II
}

\author{
By Eiji Taniguchi and Yasuyoshi Oshima* \\ Laboratory of Pesticide Chenistry, Faculty of Agriculture, \\ Kyushu University, Fukıoka \\ Received December 23, 1971
}

\begin{abstract}
From root extracts of Phryma leptostachya $\mathrm{L}$. was isolated a new lignan. Its structure has been determined to be 1-acetoxym-2-(3,4-methylenedioxy)phenoxy-6-(2-methoxy-4,5methylenedioxy)phenyl-3,7-dioxabicyclo[3.3.0]octane on the basis of the chemical properties and spectra of its degradation products.
\end{abstract}

The lignans which possess a 3,7-dioxabicyclo[3.3.0]octane ring substituted by oxy-functions known to date are gmelinol, ${ }^{1 /}$ paulownin, ${ }^{21}$ sesamolin $^{3 /}$ and phrymarolin-I. ${ }^{4}$

Gmelinol (I) and paulownin (II) are characterized by having a hydroxy group on the C-1 carbon atom of the dioxabicyclooctane ring, and sesamclin (III) by incorporating a methylenedioxyphenoxy group on the $\mathrm{C}-2$ carbon atom. Phrymarolin-I (IV) isolated from Phryma leptostachya L. is the first example of a lignan which incorporates an acetoxy group on the $\mathrm{C}-1$ carbon atom and a methoxymethylenedioxyphenoxy group on the C-2 carbon atom.

Further investigation on root extracts of Phryma leptostachya $\mathrm{L}$. had led to the isolation of another 1,2-dioxygenated-3,7-dioxabicyclo[3.3.0]octane lignan which we named phrymarolin-II. The structure (V) for phrymarolinII has been briefly reported. The detailed experimental data are described in this paper.

The ether-soluble neutral fraction of root extracts provided phrymarolin-II on silica-ge] column chromatography, where it was preceedingly eluted near to phrymarolin-I.

Phrymarolin-II gave colorless rods, $\mathrm{mp}$ $160 \sim 161^{\circ} \mathrm{C}, \quad[\alpha]_{n}+118^{\circ}$, by crystallization

\footnotetext{
* Present address: Faculty of Agriculture, Meiji University, Kawasaki.
}

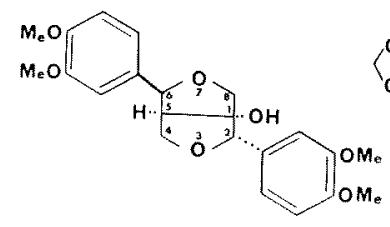

(I)

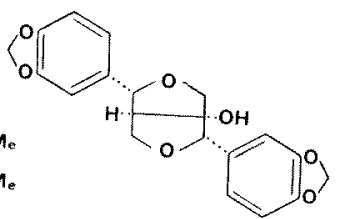

(II)<smiles>c1cc2c(cc1[C@H]1OC3COC1CO3)OCO2</smiles>

(III)<smiles>C1=CC2CCC(O1)O2</smiles><smiles></smiles><smiles>COCOC1C(c2cc3c(cc2OC)OCO3)=COC(Oc2ccc3c(c2)OCO3)C1OC(=O)O</smiles>

(v)

from ether and ethyl acetate. The crystals are soluble in acetone, ethyl alcohol and chloroform, but hardly soluble in petroleum ether. 
The molecular formula, $\mathrm{C}_{23} \mathrm{H}_{22} \mathrm{O}_{10}$, was established by elementary analysis and mass spectrometry $\left(\mathrm{M}^{+} 458\right)$.

In the IR spectrum of phrymarolin-II the presence of an acetoxy group was inferred from the absorptions at 1740 and $1230 \mathrm{~cm}^{-1}$ Absorptions at 2770,1115 and $930 \mathrm{~cm}^{-1}$ suggested the presence of a methylenedioxyphenoxy group.

In the NMR spectrum phrymarolin-II showed signals assignable to two methylenedioxy functions ( $-4.08,4.09$; each $2 \mathbf{H})$, an aromatic methoxy group ( $\tau 6.25$; singlet, $3 \mathrm{H})$, an acetoxy group ( $\tau$ 7.88; singlet, $3 \mathrm{H})$, and five aromatic hydrogens $(\tau 2.94$; singlet, $1 \mathrm{H}$, and $=3.20 \sim 3.61$; multiplet, $4 \mathrm{H}$ ).

On alkaline hydrolysis phrymarolin-II gave a monohydric alcohol, desacetyl phrymarolinII (Va), $\mathrm{C}_{21} \mathrm{H}_{20} \mathrm{O}_{9}, \quad \mathrm{mp} 98 \sim 110^{\circ} \mathrm{C}$, which showed no carbonyl absorption in the IR spectrum and did not decolorize potassium permanganate even when heated at $60^{\circ} \mathrm{C}$ for several minutes, therefore the presence of carbonyl groups and aliphatic double bonds was ruled out.

The alcohol was acetylated with acetic anhydride on boiling water for an hour to yield phrymarolin-II. The easy acetylation of the hydroxy group had been also found on desacetyl phrymarolin-I. ${ }^{4}$

Resemblance between the spectra (UV, IR and NMR) of phrymarolin-I and phrymarolin-
II, and also of their desacetyl derivatives suggested close relationship of their structures. Especially in addition to their molecular formulae, the NMR spectra implied that phry. marolin-II probably is a demethoxy-analog of phrymarolin-I. This assumption was conclusively proved by methanolysis.

On methanolysis desacetyl phrymarolin-I had yielded 2-methoxysesamol (VI) and two isomeric neutral compounds, 1-hydroxy-2methoxy-6-(2-methoxy-4, 5-methylenedioxy)phenyl - 3, 7 - dioxabicyclo [3.3.0] octanes (VII, VIII), together with the dimeric product (IX, tentatively proposed). ${ }^{4}$ With respect to desacetyl phrymarolin-II, methanolysis resulted in the production of the same neutral compounds $(\mathrm{VII} \sim \mathrm{IX})$ together with sesamol (Fig. 1). These compounds were identified on TLC and IR spectra (Figs. 2 and 3).

Then, on the ground of the structure of phrymarolin-I, it was deduced that phrymarolin-II is 1 -acetoxy-2-(3,4-methylenedioxy)phenoxy - 6(2 - methoxy - 4,5 - methylenedioxy)phenyl-3, 7-dioxabicyclo[3. 3. 0]octane (aside from stereochemistry).

The NMR spectrum of phrymarolin-II (Fig. 4) was in accord with this, and the spectrum of desacetyl phrymarolin-II was consistent with that of the 1-hydroxyderivative. In addition to the proton groups already assigned, the spectra were analyzed as presented in the Table.

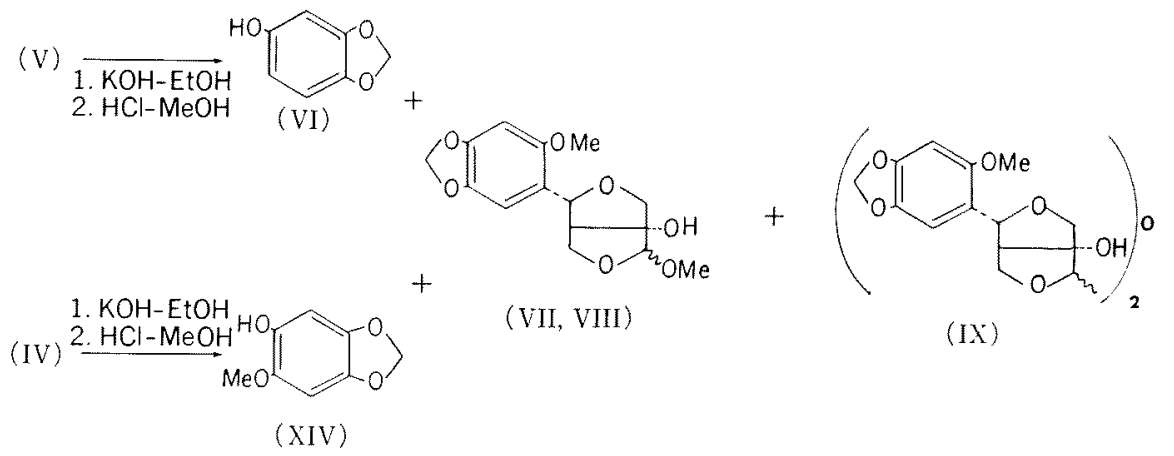

FIG. 1. 


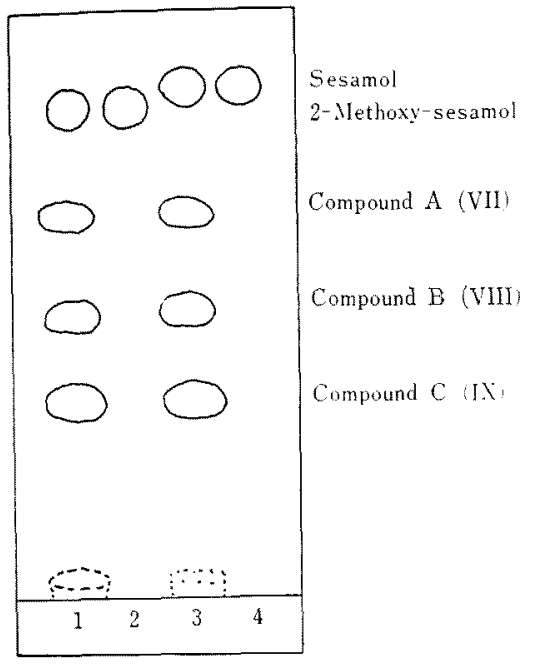

FIG. 2. TLC* of Methanolytic Products.

1. Products from desacetyl phrymarolin-I

2. 2-Methoxy-sesamol

3. Products from desacetyl phrymarolin-II

4. Sesamol

* $\mathrm{SiO}_{2} /$ Benzene-Ethyl acetate $(8: 2)$, colored by chromotropic-sulfuric acid.

The isolated oxymethylene hydrogens, 8$\mathrm{H} a$ and 8-He, displayed a couple of doublet in an $\mathrm{AB}$ system. The other oxymethylene hydrogens, 4-Ha and 4-He, constituted the $A B$ part of an $A B X$ system due to coupling with the methine hydrogen, $5-\mathrm{H}$, which in turn coupled with the benzylic ether hydrogen, 6-H to show a triplet-like multiplet. The benzylic hydrogen showed a first-order doublet. The coupling constants, $\left|J_{s a .5}\right|$ and $\left|J_{\text {te.5. }}\right|$, were tentatively obtained by analysing the couple of quartet displayed from $4-\mathrm{Ha}$ and $4-\mathrm{He}$, since the signal of $5-\mathrm{H}$ was hardly resolved into each peak. But the value of $\left|J_{4 a, 5}-J_{46.5}+J_{5,6}\right|$ was seemed to agree with the range of the signal due to the methine hydrogen.

NMR chemical shift values were employed to assign stereochemistry to phrymarolinII. That the signals of $2-\mathrm{H}, 5-\mathrm{H}$ and $8-\mathrm{He}$ were shifted downfield by acetylating the neighbouring tertiary hydroxy group indicated cis-relationship between the hydrogens and the hydroxy group ${ }^{\text {() }}$ of desacetyl phrymarolinII; otherwise an axial configuration for the methylenedioxyphenoxy group on the $\mathrm{C}-2$ carbon atom. The absence of signals at the region of $\tau 6.5 \sim 6.7$ permitted assignment of an equatorial configuration for the methoxymethylenedioxyphenyl group on the $\mathrm{C}-6$ carbon atom. ${ }^{\text {?) }}$

Thus, it was concluded that phrymarolinII possesses the same stereochemistry as phrymarolin-I.

Further evidence for the structure was provided by degradation reactions and spectral data of the products (Fig. 5).

The benzylic ether linkage was readily splitted by hydrogenation on palladium catalyst to yeild the dihydro-glycol (X), $\mathrm{C}_{21} \mathrm{H}_{24} \mathrm{O}_{9}$, mp $133 \sim 134^{\circ} \mathrm{C}$, which consisted of a primary and a tertiary hydroxy group.

The newly-born benzylic hydrogens and the neighbouring methine hydrogen resonated at the region of $\tau 7.0 \sim 7.8$ to show a complex multiplet $(3 \mathrm{H})$ in the NMR spectrum, while there disappeared the doublet signal assignable to the benzylic ether hydrogen $(6-\mathrm{H})$ of desacetyl phrymarolin-II. On the other hand, the methylene hydrogens of the newly-born hydroxymethyl group attached to an asymmetric carbon atom bearing no hydrogen showed a couple of doublet ( $\tau$ 5.56, 5.81, $\left.\left|J_{A B}\right|=12\right)$ in the NMR spectrum of the acetate (XI).

On periodate oxidation the glycol gave formaldehyde and a 3-ketotetrahydrofuran derivative which showed a carbonyl absorption at $1770 \mathrm{~cm}^{-1}$ The NMR spectrum of the ketone was in acco-d with 2-(3,4-methylenedioxy)phenoxy-4-(2-methoxy-4, 5-methylenedioxy)benzyltetrahydrofuran-3-one (XII): in addition to the proton groups on the aromatic nuclei, an isolated acetal hydrogen was appearent $(\tau 4.75,1 \mathrm{H}$, singlet), with oxymethylene hydrogens ( $\tau 5.59,5.96,2 \mathrm{H}$, octet). The 
Table I. NMR Signals of Phrymarolin-II AND

Desacetrl Phrymarolin-II.

\begin{tabular}{|c|c|c|c|c|c|c|c|c|}
\hline Assignment & $\tau$-Values & Multiplicity & $\begin{array}{l}\text { No. of } \\
\text { protons }\end{array}$ & $\tau_{.1}$ & $\tau_{B}$ & $J_{A B}$ & $J_{A X}$ & $J_{B X}$ \\
\hline \multicolumn{9}{|l|}{ Phrymarolin-II } \\
\hline $2-\mathrm{H}$ & 4.30 & s & 1 & & & & & \\
\hline $4-\mathrm{Ha}$ & $5.88,5.92,6.05,6.09$ & $\mathrm{q}$ & 1 & & 5.95 & 10 & & 1.5 \\
\hline $4-\mathrm{He}$ & $5.55,5.66,5.71,5.83$ & $\mathrm{q}$ & 1 & 5.71 & & 10 & 7.6 & \\
\hline $5-\mathrm{H}$ & $7.05 \sim 7.33$ & $\mathrm{~m}$ & 1 & & & & & \\
\hline $6-\mathrm{H}$ & $5.10,5.21$ & d & 1 & 5.15 & & & 6.5 & \\
\hline $8-\mathrm{Ha}$ & $6.15,6.33$ & $\mathrm{~d}$ & 1 & & 6.23 & 11 & & \\
\hline 8-He & $5.31,5.50$ & d & 1 & 5.40 & & 11 & & \\
\hline${ }_{-\mathrm{O}}^{-\mathrm{O}} \mathrm{CH}_{2}$ & $\begin{array}{l}4.08 \\
4.09\end{array}$ & $\begin{array}{l}\mathrm{s} \\
\mathrm{s}\end{array}$ & $\frac{2}{2}$ & & & & & \\
\hline$-\mathrm{OCH}_{3}$ & 6.25 & s & 3 & & & & & \\
\hline \multirow[t]{2}{*}{$\mathrm{ArH}$} & 2.94 & s & 1 & & & & & \\
\hline & $3.20 \sim 3.61$ & $\mathrm{~m}$ & 4 & & & & & \\
\hline$-\mathrm{OCOCH}_{3}$ & 7.88 & s & 3 & & & & & \\
\hline
\end{tabular}

Desacetyl phrymarolin-II

\begin{tabular}{lccccccc}
$2-\mathrm{H}$ & 4.75 & $\mathrm{~s}$ & 1 & & & & \\
$4-\mathrm{Ha}$ & $5.88,5.93,6.04,6.08$ & $\mathrm{q}$ & 1 & & 5.95 & 9 & \\
$4-\mathrm{He}$ & $5.53,5.65,5.68,5.80$ & $\mathrm{q}$ & 1 & 5.70 & & 9 & 7.3 \\
$5-\mathrm{H}$ & $7.36 \sim 7.63$ & $\mathrm{~m}$ & 1 & & & & \\
$6-\mathrm{H}$ & $5.04,5.15$ & $\mathrm{~d}$ & 1 & 5.10 & & & 6.5 \\
$8-\mathrm{Ha}$ & $6.22,6.38$ & $\mathrm{~d}$ & 1 & & 6.28 & 10 & \\
$8-\mathrm{He}$ & $5.60,5.77$ & $\mathrm{~d}$ & 1 & 5.72 & & 10 & \\
$-\mathrm{O} \mathrm{CH}_{2}$ & 4.09 & $\mathrm{~s}$ & 2 & & & & \\
$-\mathrm{O}$ & 4.11 & $\mathrm{~s}$ & 2 & & & & \\
$-\mathrm{OCH}$ & 6.28 & $\mathrm{~s}$ & 3 & & & & \\
$\mathrm{ArH}$ & 2.86 & $\mathrm{~s}$ & 1 & & & & \\
& $3.20 \sim 3.55$ & $\mathrm{~m}$ & 3 & & & & \\
& 3.56 & $\mathrm{~s}$ & 1 & & & & \\
$-\mathrm{OH}$ & 6.95 & $\mathrm{br}$ & 1 & & & & \\
\hline
\end{tabular}

benzylic and methine hydrogens of the ketone showed complex signals at the region of $\tau 6.85 \sim 7.45$.

On reduction with lithium aluminum hydride in dry ether the ketone quantitatively gave a monohydric secondary alcohol, $\mathrm{C}_{20} \mathrm{H}_{20} \mathrm{O}_{8}, \mathrm{mp}$ $137 \sim 139^{\circ} \mathrm{C}$, which was homogeneous on TLC. This suggested a stereoselective reduction of the chiral ketone to the all-cis alcohol (XIII), although further studies are needed to establish the stereochemistry.
Permanganate oxidation of the ketone afforded 2-methoxy-piperonylic acid (XIV) as an only recognizable product.

\section{EXPERIMENTAL}

Mps. were not corrected. NMR spectra were measured on a JNM-3H-60 spectrometer, using ca. $6 \%$ solution in deuterochloroform, with tetramethylsilane as an internal standard. Mass spectra were measured on a JMS-OISG spectrometer by direct insertion of samples. IR spectra were measured on a Shimazu IR-27G spectrometer. 


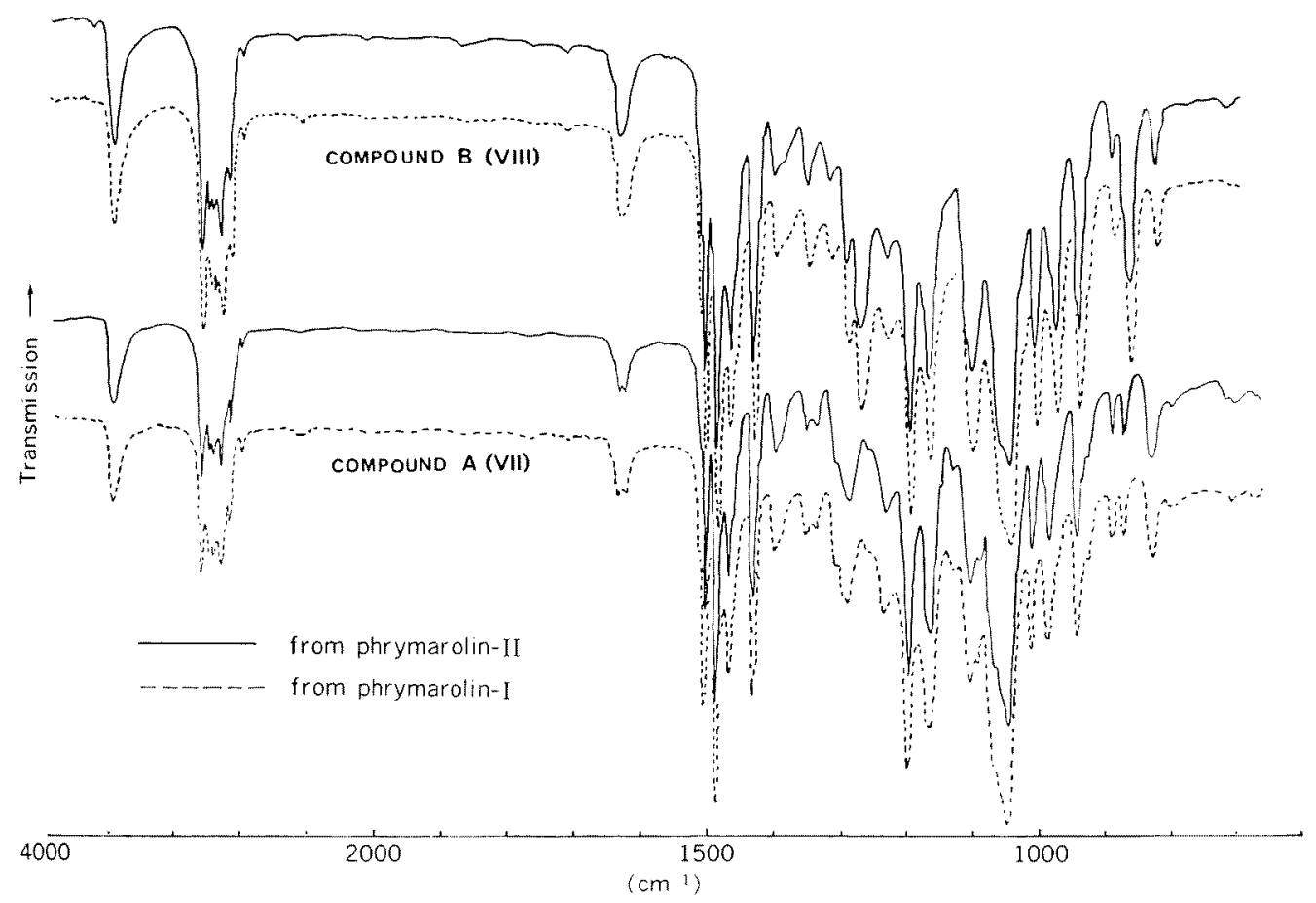

FIG. 3. IR Spectra of Compound-A and -B.

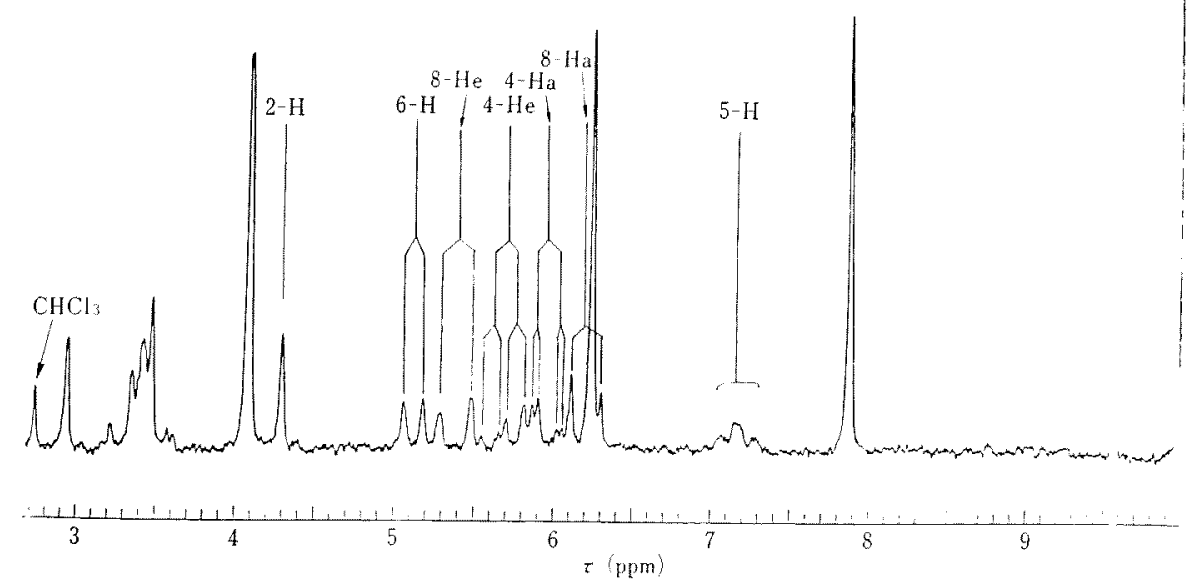

FIG. 4. NMR Spectrum of Phrymarolin-II. 

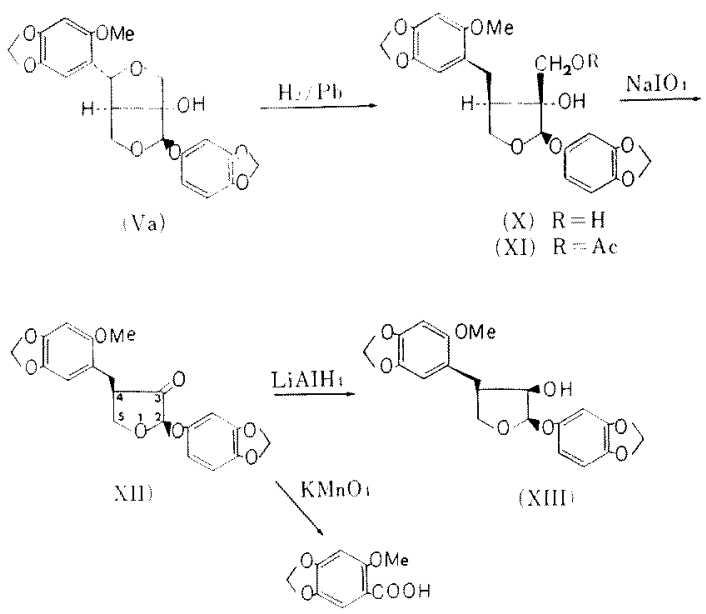

(XIV)

FIG. 5.

Isolation of phymarolin-II ( $V)$. The ether extract of $P$. leptostachya L. (15 kg, fresh root wt.) was successively extracted with $5 \%$ sodium bicarbonate, $1 \%$ sodium hydroxide, $1 \%$ sulfuric acid, and then washed with water. The ether was dried over anhydrous sodium sulfate and evaporated up to $500 \mathrm{ml}$. The concentrated solution was kept in the cool to separate precipitates of phrymarolin-I. After being decanted, the ether was removed to give a glassy material $(120 \mathrm{~g})$.

Four grams of the material was dissolved in a small quantity of benzene and put on the top of a silica gel column $14.5 \because 34 \mathrm{~cm}$, Mallinckrodt silicic acid for chromatography, 100 mesh). Elution with 1 liter of a mixture of benzene and benzine $(1: 1, v / v)$ yielded an oily residue after removal of the solvent. Further elution with $500 \mathrm{ml}$ of a mixture of benzene, benzine and ether $(10: 10: 1, \mathrm{v} / \mathrm{v})$ afforded a pale orange crystalline residue, which furnished colorless crystals by trituration with ether. Fractional crystallization from ether, ethyl acetate, and ethanol gave phrymarolin-II, colorless rods, $\mathrm{mp} 161 \sim 162^{\circ} \mathrm{C}(50 \mathrm{mg})$, with an appreciable amount of phrymarolin-I $(8 \mathrm{mg}), \mathrm{mp}$ $155 \sim 157^{\circ} \mathrm{C}$. In sum total, $1.6 \mathrm{~g}$ of phrymarolin-II were obtained. Phrymarolin-II gives a positive Labat test.

Anal. Found: $\mathrm{C}, 60.12 ; \mathrm{H}, 5.00 \%$. mol. wt. (Rast), 450. Mass $m / e: 458\left(\mathrm{M}^{+}\right)$. Calcd. for $\mathrm{C}_{23} \mathrm{H}_{22} \mathrm{O}_{10}$ : C, $60.26: \mathrm{H}, 4.84 \%$. mol wt. $458 .[\alpha]_{\mathrm{D}}+117.6^{\circ}(c=$ 2.72, dioxane). UV $\lambda_{\max }^{\mathrm{EtOH}} \mathrm{nm}(\varepsilon): 296$ (10000), 236 (8300) IR $\ln _{\max }^{K R_{r}}\left(\mathrm{~cm}^{-1}\right): 3080(w), 3000,2980,2960$, $2910,2860,2770$ (w), 1740 (s), 1630, 1615, 1501 (s), 1482 (s), 1465, 1455 (sh), 1440 (w), 1426, 1383, 1367,
$1339,1308,1276,1267,1258,1245$ (sh), 1230 (s), 1220 (sh), 1195 (sh), 1179 (s), 1155, 1140 (sh), 1128 (sh), 1115,1095 (sh), 1088, 1071, 1055, 1030 (s), 1010 (s), 980,940 (sh), 930, 919 (sh), 900, 890 (w), 860, 850, 815 (w).

Desacetyl phrymarolin-II ( $\mathrm{Va}$. A solution of phrymarolin-II $(1.16 \mathrm{~g})$ in $100 \mathrm{ml}$ of $90 \%$ ethanol containing $4 \mathrm{~g}$ of potassium hydroxide was refluxed for $2 \mathrm{hr}$. The ethanol was removed in vacuo, and the residue was dissolved in ether and the solution was washed with water and dried $\left(\mathrm{Na}_{2} \mathrm{SO}_{4}\right)$. The solvent was evaporated to give a crystalline residue. It was recrystallized from ether to give colorless prisms, mp $98 \sim 100^{\circ} \mathrm{C}(980 \mathrm{mg})$. Anal. Found: C, 60.77 ; $\mathrm{H}, 4.83$. Mass $m / e: 416.110\left(\mathrm{M}^{+}\right)$. Calcd. for $\mathrm{C}_{21} \mathrm{H}_{20} \mathrm{O}_{9}$ : C, 60.57; H, 4.84. mol. wt. 416.111. UV $\lambda_{\max }^{\mathrm{EtOH}} \mathrm{nm}$ (ह): $296.5(10030), 237(8320) . \quad \operatorname{IR} \nu_{\max }^{\mathrm{KBr}}\left(\mathrm{cm}^{-1}\right): 3540 \sim$ 3400,3040 (w), 3010, 2920 (sh), 2900, 2850 (sh), 2770 (w) $1631,1613,1500$ (s), 1485 (s), 1455, 1421, $1390(w)$, $1370(w), 1352$ (w) 1331, $1310(w), 1295$ (w), 1280, 1255, 1195 (sh), 1183 (s), 1153, 1135, 1125, 1095, 1075, 1060, 1045 (sh), 1031 (s), 995 (s), 970, 950 (w), 930, 920 (sh), $910,895(\mathrm{w}), 885,855,835,810,795$.

A solution of desacetyl phrymarolin-II $(0.45 \mathrm{~g})$ in $3 \mathrm{ml}$ of acetic anhydride was heated on an water bath for $1 \mathrm{hr}$. The reaction mixture was poured into ice. water to decompose the excess of acetic anhydride. After being dried over anhydrous sodium sulfate, the ether was removed to yield a crystalline product. It was recrystallized from ether to give colorless prisms (445 mg), mp $160 \sim 161^{\circ} \mathrm{C}$, identical with phrymarolin* II on IR and mixed mp.

Methanolysis of desacetyl phrymarolin-II. A solution of desacetyl phrymarolin-II (200 mg) in $80 \mathrm{ml}$ of distilled methanol containing $1 \mathrm{ml}$ of $35 \%$ hydrochloric acid was refluxed gently for $3 \mathrm{hr}$, then $60 \mathrm{ml}$ of the methanol was distilled out. To the remaining solution $30 \mathrm{ml}$ of $5 \%$ sodium hydroxide was added, and the solution was extracted with ether. After the separation of the ether layer, the aqueous layer was acidified with $10 \%$ hydrochloric acid and extracted with ether. The ether was washed with water, dried $\left(\mathrm{Na}_{2} \mathrm{SO}_{4}\right)$ and removed.

A brown viscous residue was triturated with petroleum ether to yield a crystalline product. It was recrystallized from petroleum ether to afford colorless plates, mp $62 \sim 64^{\circ} \mathrm{C}$. Anal. Found: C, $60.77 ; \mathrm{H}$, $4.42 \%$. Calcd. for $\mathrm{C}_{7} \mathrm{H}_{6} \mathrm{O}_{3}: \mathrm{C}, 60.87 ; \mathrm{H}, 4.38$. It was identified with sesamol on IR.

The ether layer was washed with water, dried 
( $\left.\mathrm{Na}_{2} \mathrm{SO}_{4}\right)$ and removed to yield a glassy residue. It was fractionated by preparative TLC to give two isomeric crystalline compounds, $\mathrm{mp} 120^{\circ} \mathrm{C}(35 \mathrm{mg})$ and $\mathrm{mp} 150^{\circ} \mathrm{C}(40 \mathrm{mg})$, and an amorphous substance (55 mg). They were identical with compound $A$, compound $B$ (tentatively $1-h y d r o x y-2-m e t h o x y-6(2-m e t h o x y$ 4, 5-methylenedioxy) phenyl-3, 7-dioxabicyclo [3. 3.0]octanes), and compound $C$, respectively, which were obtained from desacetyl phrymarolin-I by methanolysis, ${ }^{4 !}$ on the basis of IR, mixed mps. and cochromatography on a thin-layer plate.

Dihydrodesacetylphrymarolin-II $(X)$. Desacetyl phrymarolin-II $(950 \mathrm{mg}$ ) was dissolved in $95 \mathrm{ml}$ of ethyl acetate with suspending palladium catalyst, which was freshly prepared from $900 \mathrm{mg}$ of palladium chloride in $100 \mathrm{ml}$ of methanol. Hydrogenation was run at room temperature for $30 \mathrm{~min}$, when hydrogen was consumed about 1.3 moles per mole of desacetyl phrymarolin-II. Then the catalyst was removed from the reaction mixture and washed with $20 \mathrm{ml}$ of ethyl acetate. The combined ethyl acetate was removed in vacuo to yield a crystalline product. It was recrystallized from ether and acetone to give colorless needles, $\mathrm{mp} 135 \sim 136^{\circ} \mathrm{C}$ (560 mg). Anal. Found: C, 60.20; $\mathrm{H}, 5.37 \%$. Mass $m / e: 418\left(\mathrm{M}^{+}\right)$. Calcd. for $\mathrm{C}_{21} \mathrm{H}_{22} \mathrm{O}_{9}$ : C, $60.28 ; \mathrm{H}, 5.30 \%$. mol. wt. 418. UV $\lambda_{\max }^{\mathrm{EtOH}} \mathrm{nm}: 300$, 237. IR: $\mathrm{CHCl}_{\mathrm{max}}\left(\mathrm{cm}^{-1}\right): 3520,3250,3040$ (sh), 3010, $2950,2890,2770(\mathrm{w}), 1630,1620,1500(\mathrm{~s}), 1483(\mathrm{~s})$, $1470(\mathrm{sh}), 1465,1455$ (sh), 1421, $1380 \sim 1320(\mathrm{w}$, br), 1290 (sh), 1245, 1225, 1190 (s), 1180 (sh), 1158, 1126 , 1060 (sh), 1040 (s), 1001, 935, 850,820 (w).

$\mathrm{NMR}=\mathrm{CDCl}_{\mathrm{Y}_{4}}(\mathrm{ppm}): 3.18 \sim 3.57(5 \mathrm{H}, \mathrm{m}, \mathrm{ArH}) ; 4.09$ $(4 \mathrm{H}, \mathrm{s}$, methylenedioxy $\mathrm{H}) ; 4.50(1 \mathrm{H}, \mathrm{s}$, acetal $\mathrm{H})$; $4.9 \sim 6.5(4 \mathrm{H}, \mathrm{m}$, oxymethylene $\mathrm{H}) ; 6.24(3 \mathrm{H}, \mathrm{s}$, methoxy $\mathrm{H}), 7.05\left(2 \mathrm{H}, \mathrm{s}\right.$, hydroxy $\mathrm{H}, \mathrm{D}_{2} \mathrm{O}$ exchangeable $) ; 7.0 \sim$ $7.8(3 \mathrm{H}, \mathrm{m}$, benzylic $\mathrm{H}$ and methine $\mathrm{H})$.

The dihydro-compound was acetylated with acetic anhydride under reflux for $1 \mathrm{hr}$. The crude product was purified by preparative TLC (silica gel G/benzeneethyl acetate $(7: 3)$ ) to give an amorphous monoacetate $(X I)$.

NMR $: \mathrm{DCl}_{13}(\mathrm{ppm}): 3.19 \sim 3.51(5 \mathrm{H}, \mathrm{m}, \mathrm{ArH}) ; 4.10$ and $4.11(4 \mathrm{H}$, methylenedioxy $\mathrm{H}) ; 4.64(1 \mathrm{H}, \mathrm{s}$, acetal $\mathrm{H}) ; 5.56\left(1 \mathrm{H}, \mathrm{d}, J_{\mathrm{AB}} 12\right.$, acetoxymethyl $\left.\mathrm{H}\right) ; 5.81(1 \mathrm{H}$, d, $J_{\mathrm{AB}} 12$, acetoxymethyl $\left.\mathrm{H}\right) ; 5.8 \sim 6.42(2 \mathrm{H}$, m, oxymethylene $\mathrm{H}): 6.25(3 \mathrm{H}, \mathrm{s}$, methoxy $\mathrm{H}): 6.97 \sim 7.56(3 \mathrm{H}, \mathrm{m}$, benzylic $\mathrm{H}$ and methine $\mathrm{H}) ; 7.51(1 \mathrm{H}$, s, hydroxy $\mathrm{H}$, $\mathrm{D}_{2} \mathrm{O}$ exchangeable $) ; 7.91(3 \mathrm{H}, \mathrm{s}$, acetoxy $\mathrm{H})$.

2-(3, 4-Methylenedioxy) phenoxy-4-(2-methoxy 4,5- methylenedioxy) - benzyl-tetrahydrofiran-3-one $(X I I)$. To a solution of (X) $(70 \mathrm{mg})$ in $5 \mathrm{ml}$ of dioxanemethanol (3:1) was added $40 \mathrm{mg}$ of sodium metaperiodate in $2.5 \mathrm{ml}$ of distilled water. The mixture was allowed to stand at room temperature for $24 \mathrm{hr}$, then extracted with ether after addition of $10 \mathrm{ml}$ of distilled water. The ether layer was washed with water and dried $\left(\mathrm{Na}_{2} \mathrm{SO}_{4}\right)$, then removed. A viscous oily residue was purified by preparative TLC (silica gel $G$ /benzeneethyl acetate $(8: 2))$ to yield a colorless viscous oil. $\operatorname{IR} \nu_{\max }^{\mathrm{CHCl}} 3\left(\mathrm{~cm}^{-1}\right): 3040(\mathrm{sh}), 3010,2970(\mathrm{sh}), 2940(\mathrm{sh})$, $2900,2770(\mathrm{w}), 1770,1630,1501,1481$ (s), 1472 (sh), 1465,1455 (sh), 1435 (sh), 1425, 1360, 1330 (w), 1300 (sh), 1275, 1245, 1190 (s), 1170 (sh), 1160 (sh), 1125, $1090,1078,1060$ (sh), 1040(s), 1005, 935, $900(w), 855$, 820 .

$\mathrm{NMR}=\mathrm{Mrgs}_{4}(\mathrm{ppm}): 3.12 \sim 3.5(5 \mathrm{H}, \mathrm{m}, \mathrm{ArH}) ; 4.05$ and $4.07(4 \mathrm{H}$, methylenedioxy $\mathrm{H}) ; 4.75(1 \mathrm{H}$, o, acetal H); $5.45,5.55,5.60,5.70\left(1 \mathrm{H}, \mathrm{q}, J_{\mathrm{AB}}=9, J_{\mathrm{AX}}=6\right.$ : oxymethylene $\mathrm{H}, \mathrm{ABX}$-system $\left.{ }^{*}\right), \quad 5.85,5.90,6.00$, $6.05\left(\mathrm{tH}, \mathrm{q}, J_{\mathrm{AB}}=9, J_{\mathrm{BX}}=3 \text { : oxymethylene } \mathrm{H}\right)^{*} ; 6.24$ $(3 \mathrm{H}, \mathrm{s}$, methoxy $\mathrm{H}) ; 6.85 \sim 7.45(3 \mathrm{H}, \mathrm{m}$, benzylic and methine $\mathrm{H}$ )

The aqueous layer was subjected to steam distillation. To the distillate a 2,4-dinitrophenylhydrazine reagent was added. Yellow precipitates were collected and purified on TLC (silica gel/benzene-ethyl acetate, $8: 2)$. The crystals of mp $162 \sim 164^{\circ} \mathrm{C}$ were identified with an authentic sample of 2,4-dinitropheny/hydrazone of formaldehyde on mixed $\mathrm{mp}$ and TLC.

2-(3, 4-Methylenedioxy) phenoxy-4-(2-methoxy-4, 5methylenedioxy)benzyl-tetrahydrofuran-3-ol $(X I I I)$. To a solution of XII $(55 \mathrm{mg})$ in dry ether was added in portions $20 \mathrm{mg}$ of lithium aluminum hydride, then the mixture was allowed to stand at room temperature for $2 \mathrm{hr}$. The reaction mixture was extracted with ether after being added $10 \mathrm{ml}$ of $10 \%$ hydrochloric acid. The ether was washed with water and dried $\left(\mathrm{Na}_{2} \mathrm{SO}_{4}\right)$ and removed. A crystalline residue was recrystallized from ethanol and ether to give fine colorless needles, mp $137 \sim 139^{\circ} \mathrm{C}$. Anal. Found: C, $62.03 ; \mathrm{H}, 5.16 \%$. Mass $m / e: 388(\mathrm{M})$. Calcd. for $\mathrm{C}_{20} \mathrm{H}_{20} \mathrm{O}_{8}: \mathrm{C}, 61.85 ; \mathrm{H}, 5.19 \%$ mol. wt. 388. IR: "Incls $\left(\mathrm{cm}^{-1}\right): 3600 \sim 3300,3010,2970,2930,2870,2850(\mathrm{sh})$, 2770 (w), 1620, 1500, 1485 (s), 1470 (sh), 1465 (sh), 1455 (sh), 1420, 1385 (w, br), 1240 (sh), 1225 (sh), 1190 (s), 1156,1110 1070 (w, br), 1040 (s), 1020 (sh),

* The coupling constants, $\left|J_{\mathrm{Ax}}\right|$ and $\left|J_{\mathrm{BX}}\right|$, was tentatively obtained from the $\mathrm{AB}$ part of $\mathrm{ABX}$-system. 
1005 (sh), $930,850$.

2-16thoxy-piperonylic acid (XIV). (a) To a warm acetone solution of XII (100 mg) was added in portions $500 \mathrm{mg}$ of a pulverized mixture of potassium permanganate and magnesium sulfate $(6: 5)$ for $1 \mathrm{hr}$, and then the mixture was heated on boiling water for $4 \mathrm{hr}$. The reaction mixture was basidified with sodium hydroxide, and the hot mixture filtered. Acetone was removed, and the remained aqueous solution was extracted with ether. The manganese dioxide was washed with boiling water. The combined alkaline solution was acidified with hydrochloric acid and extracted with ether. The ether was washed with water, dried $\left(\mathrm{Na}_{2} \mathrm{SO}_{4}\right)$ and removed. A residue was purified on TLC and sublimation in vacto to afford a crystalline product. It was recrystallized from ether. The colorless crystals, mp $147 \sim 149^{\circ} \mathrm{C}$, were identified with an authentic sample of 2-methoxy-piperonylic acid on UV and cochromatography on thin-layer plates. $U V \lambda_{m a x}^{\mathrm{ELO}} \mathrm{nm}$ : $317,257,222$.

(b) A solution of desacetyl phrymarolin-II (200 mg) in acetone $(30 \mathrm{ml})$ was treated with potassium permanganate $(500 \mathrm{mg})$ for $6 \mathrm{hr}$ under reflux. Then the reaction mixture was basidified with sodium hydroxide, and the hot mixture was filtered. Acetone was removed, and a remained aqueous solution was extracted with ether. The manganese dioxide was washed with hot water. The combined alkaline solution was acidified with hydrochloric acid, and extracted with ether, the ether was washed with water, dried $\left(\mathrm{Na}_{2} \mathrm{SO}_{4}\right)$ and removed. A residue was purified on TLC and sublimation in vacto. The sublimate was recrystallized from ether to give colorless needles, $\mathrm{mp} 148 \sim 150^{\circ} \mathrm{C}$. It was identified with 2-methoxy-piperonylic acid on TLC and UV absorptions.

Acknowledgements. Our thanks are due to Prof. Y. Tomita, Faculty of Agriculture, Kyushu University for his giving us chances to use a NMR spectrometer. Mass spectra were measured by Miss Y. Inatsu of Faculty of Pharmaceutical Sciences, Kyushu University. Elementary analyses were carried out by Mr. Shido of the Center of Elementary Analysis, Kyushu University.

\section{REFERENCES}

1) A. J. Birch, G. H. Huges and E. Smith, Australian J. Chem., 7, 83 (1954); A. J. Birch and M. Smith, J. Chem., Soc., 1964, 2705.

2) K. Takahashi, T. Tanabe, K. Kobayashi and T. Nakagawa, Yakugaku Zasshi, 83, 1101 (1963); K. Takahashi and T. Nakagawa, Chem. Pharm. Bull., 14, 641 (1966).

3) E. Haslam and R. D. Haworth, J. Chem. Soc, 1955, 827; E. Haslam, J. Chem. Soc. (C), 1970, 2332.

4) E. Taniguchi and Y. Oshima, Agr. Biol. Chem., 36, 1013 (1972).

5) E. Taniguchi and Y. Oshima, ibid., 33, 466 (1969).

6) C. R. Narayanan and M. R. Sarma, Tetrahedron Letters, 1968, 1553.

7) A. J. Birch, P. L. Macdonald and A. Pelter, J. Chem. Soc. (C), 1967, 1968. 